\title{
A case report on a patient suffering from recurrent vomiting episodes, whose condition improved markedly during pregnancy and breast feeding Bodil Ohlsson*
}

\author{
Address: From the Department of Clinical Sciences, Division of Gastroenterology, Entrance 35, 20502 Malmö, Lund University, Sweden \\ Email: Bodil Ohlsson* - bodil.ohlsson@med.lu.se \\ * Corresponding author
}

Published: 21 October 2006

BMC Gastroenterology 2006, 6:28 doi:10.1 I86/147|-230X-6-28

This article is available from: http://www.biomedcentral.com/l47I-230X/6/28

(c) 2006 Ohlsson; licensee BioMed Central Ltd.

This is an Open Access article distributed under the terms of the Creative Commons Attribution License (http://creativecommons.org/licenses/by/2.0), which permits unrestricted use, distribution, and reproduction in any medium, provided the original work is properly cited.

\begin{abstract}
Background: The normal physiology of the gastrointestinal tract has been only cursorily examined. Consequently, the pathophysiology of disturbances of the gastrointestinal functions is poorly known. Recurrent vomiting is one of many functional conditions for which it is difficult to find an explanation and to treat. In the following a case is described of a patient presenting with recurrent vomiting episodes, whose condition improved spontaneously during pregnancy and breast feeding.
\end{abstract}

Case presentation: A woman with recurrent vomiting episodes over several years was examined by esophagogastroduodenoscopy. This showed a non-peristaltic ventricle. Treatment with the procinetic drug cisapride (Prepulsid ${ }^{\circledR}$ ) improved the peristalsis and reduced the symptoms. During pregnancy and breast feeding, she was free of symptoms, in spite of having discontinued her medication with cisapride (Prepulsid ${ }^{\circledR}$ ).

Conclusion: The fact that the patient improved during pregnancy and breast feeding, would seem to indicate the involvement of factors in the physiology of pregnancy and breast feeding that are of importance for gastric motility. This deserves further investigation.

\section{Background}

The normal motor function of the gut is controlled by the sympathetic and parasympathetic nervous system in addition to the enteric nervous system, interstitial cells of Cajal (ICCs) and smooth muscle cells. Severe gastrointestinal dysmotility, including gastroparesis, can develop as a result of the abnormal function of any of these systems including their associated neurotransmitters [1]. The pathogenesis may be immune-mediated, as in post-infectious gastroparesis [2], or may be due to defects in the ICCs, autonomic nervous system and smooth muscle, as in diabetic gastroparesis [3]. One third of all cases of gas- troparesis are still regarded as idiopathic [4]. Several hormones and neurotransmitters have been suggested to be involved in this condition [5]. In clinical practice, I have noticed that some patients with severe gastrointestinal motility problems have improved during pregnancy and breast feeding.

In the following, I describe a woman with recurrent vomiting and reduced gastric motility, who was completely free of problems during pregnancy and breast feeding. A hypothesis could be raised on this finding, namely, that peptides and/or neurotransmitters appearing in altered 
concentrations during these conditions are involved in the physiology and pathophysiology of the gastrointestinal tract.

\section{Case presentation}

A previously healthy woman, born in 1975, with no heredity for abdominal diseases, started to have attacks of vomiting during her teenage period. Eating late in the evening, caused her to wake up a few hours later with violent attacks of vomiting. To avoid vomiting, she had to avoid these situations and had to stay awake many hours after the last meal of the day. After some years she sought medical help for this problem. An esophagogastroduodenoscopy revealed an open cardia and a strikingly atonic, non-peristaltic ventricle. This gave rise to the suspicion of a defective emptying of the ventricle as a cause of the vomiting. The results of a histological examination of mucosal biopsies from the ventricle and duodenum were normal. Physical examination, including X-ray examination of heart and lungs, showed no abnormality. Routine blood samples were all within the normal range. She was not using any drugs. Thus, no etiology of the impaired motility could be identified.

The patient was treated with the procinetic drug cisapride (Prepulsid ${ }^{\circledR}$ ). This drug improved her symptoms with reduced vomiting, and she was able to eat in the evening. Another esophagogastroduodenoscopy, done in the course of the treatment with cisapride, showed an improved, normalized peristalsis in the ventricle. After a few years she became pregnant. She had stopped the medication with cisapride when planning the pregnancy. A light nausea was present during the first three months of pregnancy, but there was no vomiting. Thus, in spite of discontinuing the drug treatment during this period, she had no vomiting episodes. This situation continued during breast feeding, which lasted about 7 months. However, three to four weeks after the breast feeding was terminated, her attacks of vomiting resumed, and cisapride (Prepulsid ${ }^{\circledast}$ ) had to be reintroduced. When she was expecting her second child, the same sequence of events recurred. During pregnancy and breast feeding, which this time lasted for three months, there was no need of any procinetic drug. She had no nausea at all during this pregnancy. Just as after the first breast feeding, the vomiting resumed three to four weeks after the breast feeding was ceased. She did not make any changes in her dietary habits during or after her pregnancies and breast feedings.

The activity of the endocrine system of the gut is enhanced during pregnancy and lactation. Functionally, the effect of this enhanced activity is to contend with conditions of greater nutritional need by stepping up the digestive capacity and rendering the metabolism anabolic. Several of the peptides involved have been suggested to play a role in the etiology of idiopathic gastroparesis [5]. As the present patient was remarkably improved during pregnancy and breast feeding, the appropriate questions may be, which changes during these conditions also restitute impaired gastrointestinal motility, and which factors are expressed in insufficient or increased concentrations under normal conditions, leading to dysmotility.

The patient in question responded promptly to cisapride, an agent that increases acetylcholine release by acting on presynaptic serotonin $\left(5-\mathrm{HT}_{4}\right)$ receptors [6]. This suggests that serotonin and/or acetylcholine are important in this dysfunction. However, it is not known whether either of these neurotransmitters, both of which are of importance for the stimulation of gastric motility [6,7], are expressed in higher levels during pregnancy or breast feeding. The ability to respond to therapy and pregnancy and breast feeding argues against irreversible structural defects.

Several hormones of importance for gastrointestinal motility are found at higher plasma concentrations during pregnancy. One example is motilin, an important peptide in digestive motility whose receptor is the site of action for erythromycin in the treatment of gastroparesis [7]. Motilin is elevated both during pregnancy and immediately postpartum [8], whereas plasma concentrations during breast feeding have to date not been examined. The motilin-related peptide ghrelin, which originates primarily in the stomach [9], has recently also been shown to enhance gastric emptying in idiopathic gastroparesis [10]. However, this peptide is expressed at lower concentrations during pregnancy than during normal conditions [11].

Other examples of hormones appearing in increased concentrations in the plasma during pregnancy are sex hormones, which are known to delay gastrointestinal transit time [12]. Furthermore, cholecystokinin (CCK) is elevated during pregnancy and gastrin during breast feeding $[13,14]$. These changes should rather impair gastric motility, as these hormones inhibit the gastric emptying during physiological conditions [15].

Oxytocin, a hormone with well-known stimulatory effects on myoepithelial cells and uterine smooth muscles, is elevated during pregnancy and breast feeding [16,17]. Recently, oxytocin has been shown to be present throughout the human gastrointestinal tract [18]. Furthermore, it is released postprandially in healthy subjects [19]. When the oxytocin receptor antagonist atosiban was administered in conjunction with a meal, the gastric emptying rate was prolonged [20]. Taken together, these findings indicate that oxytocin may play a physiological role also in the regulation of gastric motility. 
Nitric oxide (NO) is one neurotransmitter assumed to be of interest in the etiology of diabetic gastroparesis [21]. However, NO production has been shown to be unaffected during pregnancy [22], suggesting that this is of minor interest in the case under consideration. One may further speculate about the altered profile of prostaglandins during pregnancy, but this has been only rudimentarily examined [23].

\section{Conclusion}

Altogether, the hormonal and paracrine/autocrine changes during pregnancy and breast feeding are complex, and hormones with both stimulatory and inhibitory effects on gastric emptying and motility are released in higher amounts during these conditions. By studying physiological processes during pregnancy and breast feeding, we may learn more about the physiology and pathophysiology of the gastrointestinal functions. Serotonin, motilin and oxytocin may be of great interest, and development of new agonists to these peptides calls for further research.

\section{Competing interests}

The author(s) declare that they have no competing interests.

\section{Acknowledgements}

Written consent was obtained from the patient for the publication of the study.

\section{References}

I. De Giorgio R, Camilleri M: Human enteric neuropathies: morphology and molecular pathology. Neurogastroenterol Motil 2004, 16:515-531.

2. Pande H, Lacy BE, Crowell MD: Inflammatory causes of gastro paresis. Report of five cases. Dig Dis Sci 2002, 47:2664-2668.

3. Horvath VJ, Vittal H, Ördög T: Reduced insulin and IGF-I signalling, not hyperglycemia, underlies the diabetes-associated depletion of interstitial cells of Cajal in the murine stomach. Diabetes 2005, 54: I528-1533.

4. Soykan I, Sivri B, Sarosiek I, Kiernan B, McCallum RW: Demographic, clinical characteristics, psychological and abuse profiles, treatment, and long-term follow-up of patients with gastro paresis. Dig Dis Sci 1998, 43:2398-2404.

5. Owyang C, Hasler WL: Physiology and pathophysiology of the interstitial cells of Cajal: From Bench to bedside VI. Pathogenesis and therapeutic approaches to human gastric dysrhythmias. Am J Physiol Gastrointest Liver Physiol 2002, 283:G8-G I 5.

6. Cosava M, Ritter RC, Burns GA: Cholinergic neurotransmission participates in increased food intake induced by NMDA receptor blockade. Am J Physiol Regul Integr Comp Physiol 2003, 285:R64I-648.

7. Galligan J, Vanner S: Basic and clinical pharmacology of new motility promoting agents. Neurogastroenterol Motil 2005, 1 7:643-653.

8. Holst N, Jenssen TG, Burhol PG: Plasma concentration of motilin and somatostatin are increased in late pregnancy and postpartum. Br J Obstet Gynaecol 1992, 99:338-34I.

9. Möller N, Nygren J, Hansen TK, Orskov H, Frystyk J, Nair KS: Splanchnic release of ghrelin in humans. J Clin Endocrinol Metabol 2003, 88:850-852.

10. Tack J, Depoortere I, Bisschops R, Verbeke K, Janssens J, Peeters T: Influence of ghrelin on gastric emptying and meal-related symptoms in idiopathic gastroparesis. Aliment Pharmacol Ther 2005, 22:847-853.
II. Makino Y, Hosoda H, Shibata K, Makino I, Kojima M, Kangawa K, Kawarabayashi $\mathrm{T}$ : Alteration of plasma ghrelin levels associated with the blood pressure in pregnancy. Hypertension 2002, 39:78I-784.

12. Hasler WL: The irritable bowel syndrome during pregnancy. Gastroenterol Clin N Am 2003, 32:385-406.

13. Frick G, Bremme K, Sjögren C, Lindén A, Uvnäs-Moberg K: Plasma levels of cholecystokinin and gastrin during the menstrual cycle and pregnancy. Acta Obstet Gynecol Scand 1990, 69:3 I 7-320.

14. Widström AM, Winberg J, Werner S, Svensson B, Poslocec B, UvnäsMoberg K: Breast feeding-induced effects on plasma gastrin and somatostatin levels and their correlation with milk yield in lactating females. Early Human Development 1988, 16:293-30I.

15. Scarpignato C, Varga G, Corradi C: Effect of CCK and its antagonists on gastric emptying. J Physiol 1993, 87:29I-300.

16. Chiodera P, Salvarani C, Bacchi-Modena A, Spallanzani R, Cigarani Alboni A, Gardini E, Coiro V: Relationship between plasma profiles of oxytocin and adrenocorticotropic hormone during suckling or breast stimulation in women. Horm Res 1991, 35:I19-123.

17. Silber M, Larsson B, Uvnäs-Moberg K: Oxytocin, somatostatin, insulin and gastrin concentrations vis-à-vis late pregnancy, breastfeeding and oral contraceptives. Acta Obstet Gynecol Scand 1991, 70:283-289.

18. Ohlsson B, Truedsson M, Djerf P, Sundler F: Oxytocin is expressed throughout the human gastrointestinal tract. Reg Pept 2006, I35:7-II.

19. Ohlsson B, Forsling ML, Rehfeld JF, Sjölund K: Cholecystokinin leads to increased oxytocin secretion in healthy women. Eur J Surg 2002, 168: I |4- I I8.

20. Ohlsson B, Björgell O, Ekberg O, Darwiche G: The oxytocin/vasopressin receptor antagonist delays the gastric emptying of a semisolid meal compared to saline in human. BMC Gastroenterology 6( I): I I. 2006 Mars I6,

21. Takahashi T: Pathophysiological significance of neuronal nitric oxide synthase in the gastrointestinal tract. J Gastroenterol 2003, 38:42I-430.

22. McCord N, Ayuk P, McMahon M, Boyd RCA, Sargent I, Redman C: System y+ arginine transport and NO production in peripheral blood mononuclear cells in pregnancy and preeclampsia. Hypertension 2006, 47:I09-II5.

23. Helliwell RJA, Keelan JA, Marvin KW, Adams L, Chang MC, Anand A, Sato TA, O'Carroll S, Chaiworapongsa T, Romero RJ, Mitchell MD: Gestational Age-dependent up-regulation of prostaglandin D synthase (PGDS) and production of PGDS-derived antiinflammatory prostaglandins in human placenta. J Clin Endocrinol Metabol 2006, 91 1:597-606.

\section{Pre-publication history}

The pre-publication history for this paper can be accessed here:

\section{http://www.biomedcentral.com/1471-230X/6/28/pre} pub

Publish with BioMed Central and every scientist can read your work free of charge

"BioMed Central will be the most significant development for disseminating the results of biomedical research in our lifetime. "

Sir Paul Nurse, Cancer Research UK

Your research papers will be:

- available free of charge to the entire biomedical community

- peer reviewed and published immediately upon acceptance

- cited in PubMed and archived on PubMed Central

- yours - you keep the copyright

Submit your manuscript here:

http://www.biomedcentral.com/info/publishing_adv.asp
BioMedcentral 